\title{
Effect of $c$-kit ligand, stem cell factor, on mediator release by human intestinal mast cells isolated from patients with inflammatory bowel disease and controls
}

\author{
S C Bischoff, S Schwengberg, K Wordelmann, A Weimann, R Raab, M P Manns
}

\begin{abstract}
The regulation of mediator release in human intestinal mast cells is largely unknown. Apart from IgE receptor crosslinking no secretagogues have been described so far. This study examined the effect of two cytokines (c-kit ligand and interleukin 3) and other agonists on human intestinal mast cell function. Cells were isolated from surgery specimens of 47 patients undergoing intestinal resection because of tumours or inflammatory bowel disease. Cell suspensions contained $3.6 \%$ mast cells (mean of 50 experiments). After preincubation without or with $c-k i t$ ligand or interleukin 3 , cells were stimulated by IgE receptor crosslinking, C5a or formyl-methionyl-leucyl-phenylalanine (fMLP). Histamine and sulphidoleukotriene release was measured in supernatants. The sequential stimulation of the cells with $c$-kit ligand and IgE receptor crosslinking induced the release of high amounts of histamine and leukotrienes, whereas each agonist by itself induced only marginal mediator release. Interleukin 3 induced no release by itself, but enhanced the IgE receptor dependent release, possibly by an indirect mechanism. No significant mediator release was seen in response to C5a and fMLP, even if the cells were pretreated with $c-k i t$ ligand. The mediator release, particularly that of leukotrienes, was higher in cells isolated from actively inflamed tissue from patients with inflammatory bowel disease compared with controls. In conclusion, it was found that, apart from IgE receptor crosslinking, c-kit ligand and interleukin 3 regulate mediator release in human intestinal mast cells. The enhancement of mediator release by cytokines may be of particular relevance in the pathogenesis of inflammatory bowel diseases and food intolerance reactions. (Gut 1996; 38: 104-114)
\end{abstract}

Keywords: mast cells, histamine release, $c$-kit ligand, interleukin 3, inflammatory bowel disease.

Human mast cells are characterised by metachromatic cytoplasmic granules containing proteoglycans, histamine, and proteases, and by the high affinity IgE receptor on their cellular surface. ${ }^{1-3}$ They are typically located in close association with tissue forming barriers such as the skin, mucosa, and submucosa of the gastrointestinal and the respiratory tract, and blood vessels, but also in muscular organs such as the heart and the uterus. Mast cells exert biological effects by releasing preformed mediators stored in the granules and de novo synthesised mediators such as leukotrienes, prostaglandins, and cytokines. ${ }^{34}$ The role of human mast cells in mediating allergic reactions is well known. In addition, there is increasing evidence that mast cells participate in chronic inflammatory processes such as delayed type hypersensitivities, fibrosis, and neuroimmunological disorders. ${ }^{1-5}$ Other studies suggest that mast cells not only exert proinflammatory effects but also participate in regulating repair processes such as wound healing and tissue remodelling. ${ }^{36}$ However, the pathophysiological role of mast cells in the human intestinal tract is largely unknown. Some studies indicate that intestinal mast cells may participate in food hypersensitivity reactions and other diseases such as inflammatory bowel disease. ${ }^{7-14}$ The significant occurrence of this cell type in the gut and the broad spectrum of activities of mast cell derived mediators suggests that this cell type could play a particular part in physiology and pathophysiology of the intestinal tract.

The regulation of mast cell activation is poorly understood. Apart from IgE receptor crosslinking by allergen or in vitro by IgE receptor antibodies, no triggers for mediator release have been described for human mucosal mast cells of the lung or the intestine. ${ }^{2}{ }^{3}$ In contrast, human skin mast cells can be triggered for mediator release by IgE dependent and IgE independent stimuli such as the anaphylatoxin $\mathrm{C} 5 \mathrm{a}$ and the neuropeptide substance P. ${ }^{15} \mathrm{Rat}$ peritoneal mast cells release histamine in response to nerve growth factor, interleukin 3 (IL 3), and substance P. ${ }^{12}$ However, human lung and skin mast cells do not release mediators in response to nerve growth factor and substance $P$, and they lack the IL 3 receptor, ${ }^{16} 17$ showing a fundamental difference between human and rodent mast cells. Several studies showed that particular growth factors also regulate effector functions in mature cells. For example, the haematopoietic growth factors IL 3, IL 5, and GM-CSF promote the development of basophils and eosinophils, and strongly modulate the release of mediators in mature basophils and eosinophils. These three cytokines induce no or only marginal mediator release in themselves, but strongly enhance the 
release reaction induced by different $\operatorname{IgE}$ dependent and IgE independent triggering agents. ${ }^{18-20}$ This effect has been termed 'priming' and was seen in basophils, eosinophils, neutrophils, and monocytes in an analogous way, and thus seems to be a general mechanism for the regulation of inflammatory effector cell functions. By contrast, the knowledge on cytokines modulating human mast cell function is poor. In the rodent system, a number of cytokines (IL 3, IL 4, IL 9, IL 10) could be identified that regulate the development or the effector functions, or both of mast cells. $^{2}$ However, these findings could not be transferred to the human system. All these cytokines failed to affect mediator release in human lung mast cells, further emphasising the functional difference between rodent and human mast cells. ${ }^{16}$ The effect of cytokines on human intestinal mast cells has not been examined before.

Recently, a novel growth factor named stem cell factor or $c-k i t$ ligand has been identified in rodents and humans. ${ }^{21} \mathrm{C}$-kit ligand binds to the proto-oncogene $c-k i t$ and acts as a growth factor on bone marrow progenitor cells in synergism with IL 3, G-CSF, GM-CSF, and erythropoietin. In particular, it promotes the development of mast cells from CD34+ stem cells in vitro and in vivo. Apart from its role as a growth factor for mast cells and other bone marrow derived cell lineages, the biological relevance of $c$-kit ligand is poorly understood. In previous studies, we showed that $c$-kit ligand strongly modulates the function of mature human lung mast cells. ${ }^{16} 22 \mathrm{~A}$ short preincubation with $c$-kit ligand enhances the release of histamine and leukotrienes in lung mast cells in response to IgE receptor crosslinking. In addition, $c-k i t$ ligand induces mediator release in human skin mast cells and participates in the pathogenesis of cutaneous mastocytosis. ${ }^{23} 24$ Thus, $c-k i t$ ligand is a unique cytokine modulating human lung and skin mast cell function. We have examined the effect of two cytokines, $c$-kit ligand and IL 3, on mediator release by human intestinal mast cells. Cells were isolated from tissue specimens obtained from patients undergoing surgery for complications of inflammatory bowel disease. Normal tissue derived from tumour patients undergoing bowel resection served as control. The release reaction in response to $c$-kit ligand and other agonists was compared in mast cells isolated from different intestinal sections.

\section{Methods}

\section{Patients}

Fifty experiments were performed with mast cells isolated from surgery specimens of human intestinal tissue. The study includes 47 patients; 25 patients with intestinal tumours (six colon carcinoma, nine rectum carcinoma, four sigmoid carcinoma, six pancreas carcinoma with resection of the duodenum), 10 patients with active Crohn's disease, two patients with active ulcerative colitis, and 10 patients with other intestinal diseases (two duodenal polyps, three colon polyps, one intestinal sarcoma, one $x$ ray induced stenosis, two diverticulosis). Permission to conduct the study on intestinal tissue was given by the ethical committee of the Medical School of Hannover. Table I gives further patient data. Inflamed tissue was obtained from 13 patients (10 Crohn's disease, two ulcerative colitis, one inflamed colon polyp). Macroscopically normal tissue was obtained from 37 patients (25 tumour disease, three Crohn's disease, nine other disease). Thus, both inflamed and non-inflamed tissue could be obtained in three of the patients with Crohn's disease. Noninflamed tissue from patients with no evidence for intestinal inflammatory disease was taken from macroscopically normal areas of the resected tissue most far away from the tumour and served as control tissue $(n=34)$.

\section{Reagents and buffers}

HEPES, D-glucose, gelatin type B, chymopagain, and acetylcystein were from Sigma (München, Germany); ampicillin was from Bayer AG (Leverkusen, Germany); gentamycin, phosphate buffered saline (PBS) buffer without $\mathrm{MgCl}_{2} / \mathrm{CaCl}_{2}$ was from $\mathrm{Gibco}$ (Berlin, Germany); metronidazol was from Fresenius AG (Bad Homburg, Germany); DNAse, bovine serum albumin fraction $\mathrm{V}$, pronase, collagenase $\mathrm{D}$, elastase were from Boehringer AG (Mannheim, Germany). All other chemicals were of highest purity available. Tyrode's solution contains $137 \mathrm{mM} \mathrm{NaCl}, 2.7 \mathrm{mM} \mathrm{KCl}$, $0.36 \mathrm{mM} \mathrm{Na} \mathrm{HPO}_{4}$, and $5.55 \mathrm{mM}$ glucose. TE is Tyrode's solution containing $2 \mathrm{mM}$ EDTA. TEA is TE containing antibiotics (ampicillin $200 \mu \mathrm{g} / \mathrm{ml}$, gentamycin $200 \mu \mathrm{g} / \mathrm{ml}$, metronidazol $40 \mu \mathrm{g} / \mathrm{ml}$ ). TGMD is Tyrode's solution supplemented with $1.23 \mathrm{mM} \mathrm{MgCl}$, $15 \mu \mathrm{g} / \mathrm{ml}$ DNAse, and $1 \mathrm{mg} / \mathrm{ml}$ gelatin.

TABLE I Patient characteristics and cell harvest

\begin{tabular}{|c|c|c|c|c|c|c|c|c|c|c|}
\hline Disease & $\begin{array}{l}\text { Experiments } \\
(n)\end{array}$ & $\begin{array}{l}\text { Age } \\
(y)\end{array}$ & $\begin{array}{l}\text { Sex } \\
(m: f)\end{array}$ & $\begin{array}{l}\text { Site of } \\
\text { resection } \\
(S I / L I / R S)^{\star}\end{array}$ & $\begin{array}{l}\text { Inflamed } \\
\text { tissue } \\
(n)\end{array}$ & $\begin{array}{l}\text { Total tissue } \\
\text { weight } \\
\text { (g) }\end{array}$ & $\begin{array}{l}\text { Mucosal } \\
\text { submucosa } \\
\text { weight }(g)\end{array}$ & $\begin{array}{l}\text { Cells } \ddagger \\
\text { total } \\
\left(\times 10^{6}\right)\end{array}$ & $\begin{array}{l}\text { Cells } \ddagger \\
\text { fraction } 1-2 \\
\left(\times 10^{6}\right)\end{array}$ & $\begin{array}{l}\text { Cells } \ddagger \\
\text { fraction 3-4 } \\
\left(\times 10^{6}\right)\end{array}$ \\
\hline $\begin{array}{l}\text { Tumour } \\
\text { (25 patients) }\end{array}$ & 25 & $61(2)$ & $16: 9$ & $6 / 6 / 13$ & 0 & $\begin{array}{l}14 \cdot 8(1 \cdot 9) \\
(5 \cdot 1-43 \cdot 1)\end{array}$ & $\begin{array}{l}5.9(0.6) \\
(2 \cdot 9-16.0)\end{array}$ & $\begin{array}{c}112(15) \\
(13-242)\end{array}$ & $34(10)$ & $74(8)$ \\
\hline $\begin{array}{c}\text { Crohn's disease } \\
\text { (10 patients) }\end{array}$ & 13 & $\begin{array}{l}29(2) \\
(21-47)\end{array}$ & $8: 5$ & $5 / 8 / 0$ & 10 & $\begin{array}{c}6.9(0.7) \\
(3.9-9 \cdot 2)\end{array}$ & $\begin{array}{c}2 \cdot 3(0 \cdot 4) \\
(1 \cdot 0-4 \cdot 2)\end{array}$ & $\begin{array}{c}93(26) \\
(7-205)\end{array}$ & $\begin{array}{c}49(13) \\
(3-88)\end{array}$ & $\begin{array}{c}56(14) \\
(5-117)\end{array}$ \\
\hline $\begin{array}{l}\text { Ulcerative colitis } \\
\text { (2 patients) }\end{array}$ & 2 & $55(42-68)$ & $1: 1$ & $1 / 1 / 0$ & 2 & $\begin{array}{l}15 \cdot 1 \\
(9 \cdot 1-21 \cdot 1)\end{array}$ & $\begin{array}{l}5 \cdot 8 \\
(3 \cdot 6-8)\end{array}$ & $\begin{array}{l}177 \\
(168-187)\end{array}$ & $16(2-31)$ & $16(156-166)$ \\
\hline $\begin{array}{l}\text { Other } \\
\text { (10 patients) }\end{array}$ & 10 & $\begin{array}{l}45(5) \\
(24-69)\end{array}$ & $7: 3$ & $4 / 2 / 4$ & 1 & $\begin{array}{r}13 \cdot 2(3 \cdot 7) \\
(4 \cdot 2-20 \cdot 6)\end{array}$ & $\begin{array}{l}5 \cdot 7(1 \cdot 3) \\
(1 \cdot 5-10 \cdot 0)\end{array}$ & $\begin{array}{l}93(23) \\
(14-242)\end{array}$ & $\begin{array}{c}27(9) \\
(2-62)\end{array}$ & $\begin{array}{l}61(15) \\
(5-138)\end{array}$ \\
\hline All (47 patients) & 50 & $\begin{array}{l}49(2) \\
\quad(21-82)\end{array}$ & $32: 18$ & $15 / 17 / 18$ & 13 & $\begin{array}{c}12 \cdot 4(1 \cdot 3) \\
(3 \cdot 9-43 \cdot 1)\end{array}$ & $\begin{array}{l}5 \cdot 2(0.5) \\
\quad(1 \cdot 0-16.0)\end{array}$ & $\begin{array}{c}105(12) \\
(7-241)\end{array}$ & $\begin{array}{l}35(6) \\
\quad(1-140)\end{array}$ & $\begin{array}{l}71(7) \\
\quad(5-166)\end{array}$ \\
\hline
\end{tabular}

$\star S I=$ small intestine, $\mathrm{LI}=$ large intestine, $\mathrm{RS}=$ rectosigmoid; tweight of tissue specimen before (total tissue weight) and after (mucosa/submucucosa weight) dissection from the underlying muscle layers; $\neq$ cell harvest from all digestion steps (cells total), from the 1 st and 2 nd digestion step (cells fraction $1+2$ ), and from the 3rd and 4th digestion step (cells fraction $3+4)$; mean (SEM) and range shown. 
HEPES buffer contains $20 \mathrm{mM}$ HEPES, 125 $\mathrm{mM} \mathrm{NaCl}, 0.5 \mathrm{mM}$ D-glucose, and $5 \mathrm{mM}$ $\mathrm{KCl}$. HA is HEPES buffer supplemented with $0.25 \mathrm{mg} / \mathrm{ml}$ bovine serum albumin. HACM is $\mathrm{HA}$ supplemented with $1 \mathrm{mM} \mathrm{CaCl}$ and $1 \mathrm{mM} \mathrm{MgCl}$.

\section{Cell stimuli}

The soluble form of purified human recombinant $c$-kit ligand was kindly provided by Hoffmann-La Roche (Basle, Switzerland). Human recombinant IL 3 was a gift of Sandoz (Basle, Switzerland). C-kit ligand and IL 3 were diluted in HEPES buffer containing $1 \mathrm{mg} / \mathrm{ml}$ bovine serum albumin to a concentration of $100 \mu \mathrm{g} / \mathrm{ml}$ (c-kit ligand) and $10 \mu \mathrm{g} / \mathrm{ml}$ (IL 3). The cells were incubated with final concentrations of $100 \mathrm{ng} / \mathrm{ml} \mathrm{c}$-kit ligand or $10 \mathrm{ng} / \mathrm{ml} \mathrm{IL} 3$. Mast cells were triggered by the purified antibody mAb 29C6, which is directed against a non-IgE binding epitope of the high affinity IgE receptor $\alpha$ chain. This antibody, which binds with high affinity to the Fcel receptor $(\mathrm{Kd}=3.2 \mathrm{nM})$ was obtained from Hoffmann-La Roche (Nutley, NJ). It was diluted to $50 \mu \mathrm{g} / \mathrm{ml}$ and used at a final concentration of $100 \mathrm{ng} / \mathrm{ml}$. Formyl-methionyl-leucyphenylalanine (fMLP) was from Bachem AG, Bubendorf, Switzerland, and was diluted in PBS/20 mM HEPES to a concentration of $250 \mu \mathrm{M}$, and used at a final concentration of $2.5 \mu \mathrm{M}$. C5a was purified from human serum as described, ${ }^{15}$ and used at a final concentration of $10 \mathrm{nM}$. All substances were stored in small aliquots at $-80^{\circ} \mathrm{C}$. The final concentrations of the stimuli have been selected with the intention to use maximally effective concentrations. Because of the limited cell numbers that could be isolated from the patients, dose response experiments could not be performed. Therefore, we chose the concentrations from data in published reports. Dose response studies performed in human lung mast cells showed that $c$-kit ligand is maximally effective above 10 $\mathrm{ng} / \mathrm{ml}, \mathrm{mAb} 29 \mathrm{C} 6$ at $100 \mathrm{ng} / \mathrm{ml} .{ }^{16} \mathrm{IL} \mathrm{3,} \mathrm{C5a,}$ and fMLP do not affect human lung mast cells but do affect human basophils. In such experiments, IL 3 has been shown to be maximally effective above $1 \mathrm{ng} / \mathrm{ml}$, C5a above $1 \mathrm{nM}$, fMLP above $1 \mu M .{ }^{18} 19$ Thus, based on the assumption that the results obtained with human lung mast cells and basophils are transferable to intestinal mast cells the concentrations of agonists used should be maximally effective.

\section{Cell preparation}

Human lamina propria and submucosa cells containing mast cells were isolated from intestinal specimens by a four step enzymatic tissue dispersion method as described previously ${ }^{16}$ with some modifications. Immediately after resection, the tissue was placed in ice cold TEA solution and stored at $4^{\circ} \mathrm{C}$. The tissue was processed either immediately (within one hour after resection, 21 experiments) or the following day (15-20 hours after resection, 29 experiments). Cell isolation was started by separating the mucosa/submucosa from the muscularis/serosa by scissors, and both the whole tissue and the separated mucosa/submucosa was weighed (wet weight; Table I). The separated tissue was cut into $1 \times 1 \mathrm{~cm}$ fragments and incubated in TE solution containing $1 \mathrm{mg} / \mathrm{ml}$ acetylcystein for 10 minutes at room temperature to remove mucus, and then in TEA solution containing $5 \mathrm{mM}$ EDTA for 15 minutes at $37^{\circ} \mathrm{C}$ to detach epithelial cells. After washing in TE solution, the tissue was incubated in TE containing $3 \mathrm{mg} / \mathrm{ml}$ pronase and $0.75 \mathrm{mg} / \mathrm{ml}$ chymopapain at room temperature. During this first digesting step the tissue was chopped finely with scissors. After 30 minutes the free cells (fraction 1) were separated from tissue fragments by filtration through a polyamid Nybolt filter (pore size $300 \mu \mathrm{m}$, Swiss Silk Bolting Cloth Manufacturing, Zürich, Switzerland). The remaining tissue fragments were washed in $\mathrm{TE}$ and the first digestion step was repeated at $37^{\circ} \mathrm{C}$ (fraction 2 ). The tissue fragments were then washed in TGMD solution and incubated twice for 30 minutes at $37^{\circ} \mathrm{C}$ in TGMD containing $1.5 \mathrm{mg} / \mathrm{ml}$ collagenase $\mathrm{D}$ and 0.15 $\mathrm{mg} / \mathrm{ml}$ elastase. Again, the freed cells were separated from the digested tissue by filtration (fraction 3 and 4). The cells of fraction 1 and 2 and the cells of fraction 3 and 4 were pooled, washed in HA buffer, filtered through a Nybolt filter (pore size $100 \mu \mathrm{m}$ ), washed again, and resuspended in HA buffer.

\section{Cell counting and differentiation}

In all experiments, cell fraction $1+2$ and cell

TABLE II Cell differentiation and histamine content per mast cell

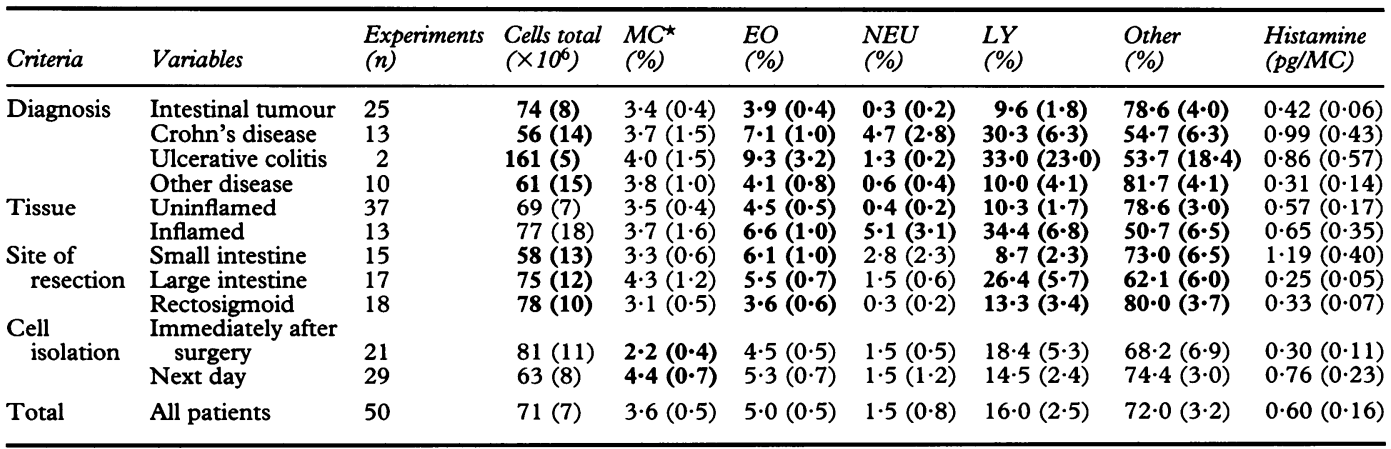

${ }^{\star} \mathrm{MC}=$ mast cells, $\mathrm{EO}=$ eosinophils, $\mathrm{NEU}=$ neutrophils, $\mathrm{LY}=$ lymphocytes, Other=other cell types (tissue cells); data are presented as mean (SEM). Bold values show criteria, the variables of which influence the number/percentage of cells (analysis of variances, see Methods). 
fraction $3+4$ were counted in a Neubauer counting chamber (diluted $1: 10$ in Türk's solution) and differentiated (cytocentrifuge smears stained with May-Grünwald/Giemsa). Fraction $1+2$ contained 35 (6) million cells (mean (SEM) of 50 experiments) and 0.51 $(0 \cdot 13)$ million $\mathrm{MC}(=1.6 \%)$, fraction $3+4$ contained 71 (7) million cells and $2.09(0.32)$ million mast cells $(=3.6 \%)$. The mean total cell harvest was 8.5 million cells per $g$ tissue $(=20.2$ million cells per $\mathrm{g}$ mucosa/submucosa), the mast cell harvest was 0.21 million mast cell per $\mathrm{g}$ tissue $(=0.51$ million mast cells per $g$ mucosa/submucosa). Table II shows the composition of the isolated cell suspensions used for the release experiments (fraction $3+4$ ). Trypan blue staining showed $70 \%$ (fraction $1+2$ ) and $85 \%$ (fraction $3+4$ ) intact cells, the damaged cells being nearly exclusively epithelial cells. No difference was seen in viability of mast cells after overnight storage of the tissue before starting the cell isolation. By contrast, when comparing the cells isolated immediately after surgery and one day later, the second preparations showed higher percentages of mast cells (Table II) and higher numbers of granules in the cytoplasma suggesting a 'reconstitution' of mast cell granules during the storage of the tissue.

\section{Mediator release assay}

Only cells of fraction $3+4$ were used for release experiments, because fraction $1+2$ contained comparatively high numbers of neutrophils (mean: $7 \cdot 6 \%$, versus $1.5 \%$ in fraction $3+4$ ), which may result from a contamination with blood cells. To minimise the risk of contaminating blood derived basophils $(0.21 \%$ in fraction $1+2,<0.1 \%$ in fraction $3+4)$ and to enhance the percentage of mast cells, the cell fractions $1+2$ were discarded. Prior to the experiment, cells of fraction $3+4$ were suspended in HACM buffer at a concentration of $3.6(0.4) \times 10^{6}$ cells per $\mathrm{ml}$ (corresponding to 100 (11) $\times 10^{3}$ mast cells $/ \mathrm{ml}$, mean (SEM), range: $10-310 \times 10^{3}$ mast cells $\left./ \mathrm{ml}\right)$ and distributed into tubes ( $1 \mathrm{ml} /$ tube). Experiments were only performed if fraction $3+4$ contained at least $100 \times 10^{3}$ mast cells in total. The release experiments were performed in a shaking water bath at $37^{\circ} \mathrm{C}$ as described. ${ }^{18-20}$ After a warming up period of 10 minutes the cells were preincubated with or without cytokines for 15 minutes, followed by the addition of the triggering agent. The release reaction was stopped 35 minutes after addition of the triggering agent by placing the tubes in ice cold water (total incubation time = one hour). Cells were separated from supernatants by centrifugation $\left(400 \times \mathrm{g}, 10 \mathrm{~min}, 4^{\circ} \mathrm{C}\right)$ and the supernatants were stored at $-80^{\circ} \mathrm{C}$ until histamine and sulphidoleukotrienes were measured.

\section{Measurements of mediators}

For each experiment the total amount of histamine per tube was determined. For each experiment the total amount of cellular histamine was measured in quadruplicates. Cell suspensions were diluted $1: 1$ in distilled water and sonocated. The lysates were centrifuged $\left(1000 \times g, 10 \mathrm{~min}, 4^{\circ} \mathrm{C}\right)$ and supernatants were also stored at $-80^{\circ} \mathrm{C}$ for histamine measurements. Histamine was measured by a competitive solid phase radioimmunoassay using an antibody recognising acetylated histamine (Dianova-Immunotech SA, Hamburg, Germany). Histamine content per mast cell was $0.60(0.16) \mathrm{pg} /$ mast cell (mean (SEM), $\mathrm{n}=35$, see Table II). Histamine release was expressed as per cent release of total cellular histamine content. Sulphidoleukotrienes were measured by a fluid phase radioimmunoassay using a $\mathrm{mAb}$ recognising leukotriene C4 (LTC4) equally well as its metabolites LTD4 and LTE4. ${ }^{20}$ Such an antibody is preferable to other $\mathrm{mAbs}$ specific for LTC4, as the use of a mAb with equal affinity for all sulphidoleukotrienes eliminates the possibility that the leukotriene measurements are dependent on variations in LTC4 metabolism. Leukotriene data were expressed as pg per $10^{6}$ mast cell. Eleven of 50 experiments $(22 \%)$ had to be excluded from analysis of histamine release, because total cellular histamine content per tube was below $5 \mathrm{nM}$, and therefore, mediator release was no longer measurable (detection limit of the assay= $1 \mathrm{nM}$ ). Twenty nine of 50 experiments $(58 \%)$ had to be excluded for analysis of sulphidoleukotriene production, because no leukotrienes could be detected under any experimental condition (detection limit of the sulphidoleukotriene assay $=3 \mathrm{pg} /$ tube). In nine experiments both histamine and leukotrienes were not detectable. The number of mast cells per tube was slightly smaller in the excluded experiments compared with the experiments in which mediators were measurable. Nevertheless, these small differences in mast cell numbers are not sufficient to explain the failure to detect mediators in, respectively, 11 and 29 of 50 experiments. It is probable that some cell preparations may be damaged during tissue resection or during the five hours cell isolation procedure, although such functional deficiencies are not necessarily shown by Trypan blue staining.

\section{Immunohistochemistry}

Mucosal biopsy specimens from 52 patients (20 with Crohn's disease, 22 with ulcerative colitis, 10 controls without evidence of inflammatory bowel disease) were fixed in paraformaldehyde $4 \%$, embedded in paraffin wax, and sequentially sectioned at $3 \mu \mathrm{m}$. Sections were applied to slides coated with APES (3-aminopropyl-triethoxysilan), and, after deparaffinisation and hydration, pretreated with target unmasking fluid (Dianova, Hamburg, Germany), hydrogen peroxide 3\%, and goat non-immune serum (Dako Diagnostics, Hamburg, Germany). Subsequently, sequential sections were incubated for 60 minutes at room temperature with the primary antibody, either mouse antihuman tryptase $\mathrm{mAb}$ (Chemikon, Temecula, CA) at 0.25 $\mu \mathrm{g} / \mathrm{ml}$, or affinity purified rabbit antihuman $c$-kit pAb (Oncogene Science, Uniondale, NY) at $2.5 \mu \mathrm{g} / \mathrm{ml}$. After washing, sections were 
incubated with a biotinylated secondary antibody for 30 minutes, streptavidin conjugated horseradish peroxidase for 30 minutes, and hydrogen peroxide for five minutes (all reagents from Dako Diagnostics). Positive cells within a defined area of lamina propria $(400 \mu \mathrm{m} \times 500 \mu \mathrm{m})$ were counted and expressed as cells per $\mathrm{mm}^{2}$ of lamina propria.

Statistics

All experiments were performed in duplicate and each supernatant was measured twice. Thus, four values were obtained for each condition, and the mean was calculated. Data from several experiments are presented as mean (SEM), if not indicated otherwise. For comparison of multiple experimental conditions or more than two patient groups data were analysed by analysis of variance (multiple comparisons) using the software package SPSS release 6.0. For multiple comparisons of paired group means the Duncan method was used provided that differences of the means could
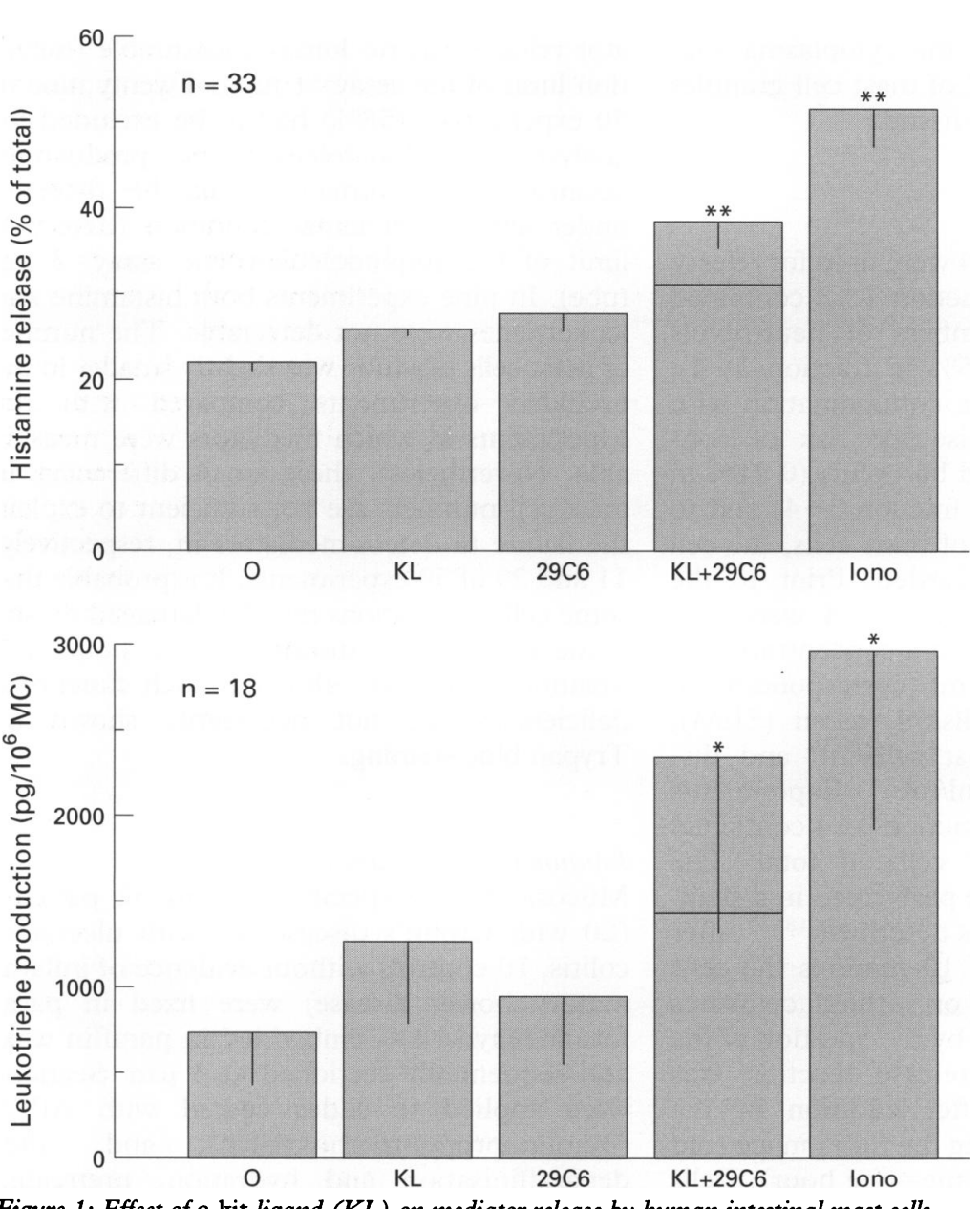

Figure 1: Effect of c-kit ligand (KL) on mediator release by human intestinal mast cells. Cells were preincubated in buffer $(O, 29 \mathrm{C6}$, iono) or with $100 \mathrm{ng} / \mathrm{ml}$ human $K L(K L$, $\mathrm{KL}+29 \mathrm{C} 6$ ) for 15 minutes and then stimulated with $100 \mathrm{ng} / \mathrm{ml}$ anti-IgE receptor $\mathrm{mAb}$ $29 \mathrm{C6}\left(29 \mathrm{C} 6, \mathrm{KL}+29 \mathrm{C6}\right.$ ) or with $1 \mu M$ ionomycin (iono) for 35 minutes at $37^{\circ} \mathrm{C}$. $O=$ buffer control. Histamine release (expressed as \% of total cellular histamine before stimulation, upper panel) and leukotriene production ( $\mathrm{pg}$ sulphidoleukotrienes per $10^{6}$ mast cells, lower panel) is shown. The mean (SEM) of 33 (upper panel) and 18 (ower panel) experiments performed in duplicate is shown. The horizontal line in the 4th column from the left $(K L+29 C 6)$ shows the predicted additive effect of $K L$ and $m A b 29 C 6$. Statistical analysis (Duncan method, see text): ${ }^{\star} p<0.05,{ }^{\star \star} p<0.01$ for a significant difference to the spontaneous release $(O)$, other significant differences in histamine release: iono versus $K L$, iono versus $29 C 6$, iono versus $K L+29 C 6, K L+29 C 6$ versus $K L, K L+29 C 6$ versus $29 C 6$ (all $p<0.01$ ), in leukotriene production: iono versus $29 C 6, K L+29 C 6$ versus $29 C 6$ (both $p<0.05)$. be assumed. ${ }^{25}$ If two patient groups were compared, the two tailed $t$ test for independent samples was used. For correlation analyses, the correlation coefficient and the probability for the hypothesis that the slope of the regression curve is different from zero (modified $F$ test) was calculated.

\section{Results}

Effect of c-kit ligand on mediator release by human intestinal mast cells

Figure 1 shows that human intestinal cells containing mast cells spontaneously release histamine and sulphidoleukotrienes within an incubation time of one hour at $37^{\circ} \mathrm{C}$. Both $c-k i t$ ligand and mAb $29 \mathrm{C} 6$ by themselves induced the release of small amounts of histamine and sulphidoleukotrienes albeit not significant in statistical means. Most interestingly, the preincubation with $c$-kit ligand rendered cells capable of releasing large amounts of preformed and de novo synthesised mediators in response to otherwise hardly effective $\mathrm{IgE}$ receptor crosslinking. As expected, the receptor independent stimulation by ionomycin, which served as a positive control in those experiments, caused the most pronounced release reaction in intestinal mast cells. The sequential stimulation of mast cells with $c$-kit ligand and mAb 29C6 induced a release reaction comparable to that induced by 'unphysiological' receptor independent triggers such as ionomycin. In almost all experiments preincubation with $c$-kit ligand caused an enhancement of the IgE receptor dependent release of histamine (mean (SEM) 46 (10)\% enhancement, range: 3-250\%, $\mathrm{p}<0.01)$ and of leukotrienes (235 (112)\% enhancement, range: $4-2113 \%, p<0.05)$, albeit to variable degrees.

\section{IL 3 enhances mast cell mediator release}

In contrast with $c$-kit ligand, the haematopoietic growth factor IL 3 induced almost no mediator release by itself in human intestinal mast cells. However, IL 3 also enhanced the histamine and leukotriene release induced by stimulation with the mAb $29 \mathrm{C} 6$. The enhancement by IL 3 preincubation was clearly less pronounced compared with the effect of $c$-kit ligand preincubation (Fig 2).

\section{Mediator release by $f M L P$ and $C 5 a$}

The anaphylatoxin $\mathrm{C} 5 \mathrm{a}$ and the bacterial product $\mathrm{MLP}$ induced small amounts of histamine release (statistically not significant, Fig 3) and sulphidoleukotriene production (data not shown). In contrast with IgE receptor crosslinking, the effects of both chemotactic agonists were not enhanced by $c-k i t$ ligand preincubation suggesting that their marginal effects on mediator release may be mast cell independent.

Mast cells as the source of histamine and leukotrienes

Figure 4 (A) shows that the total histamine per 

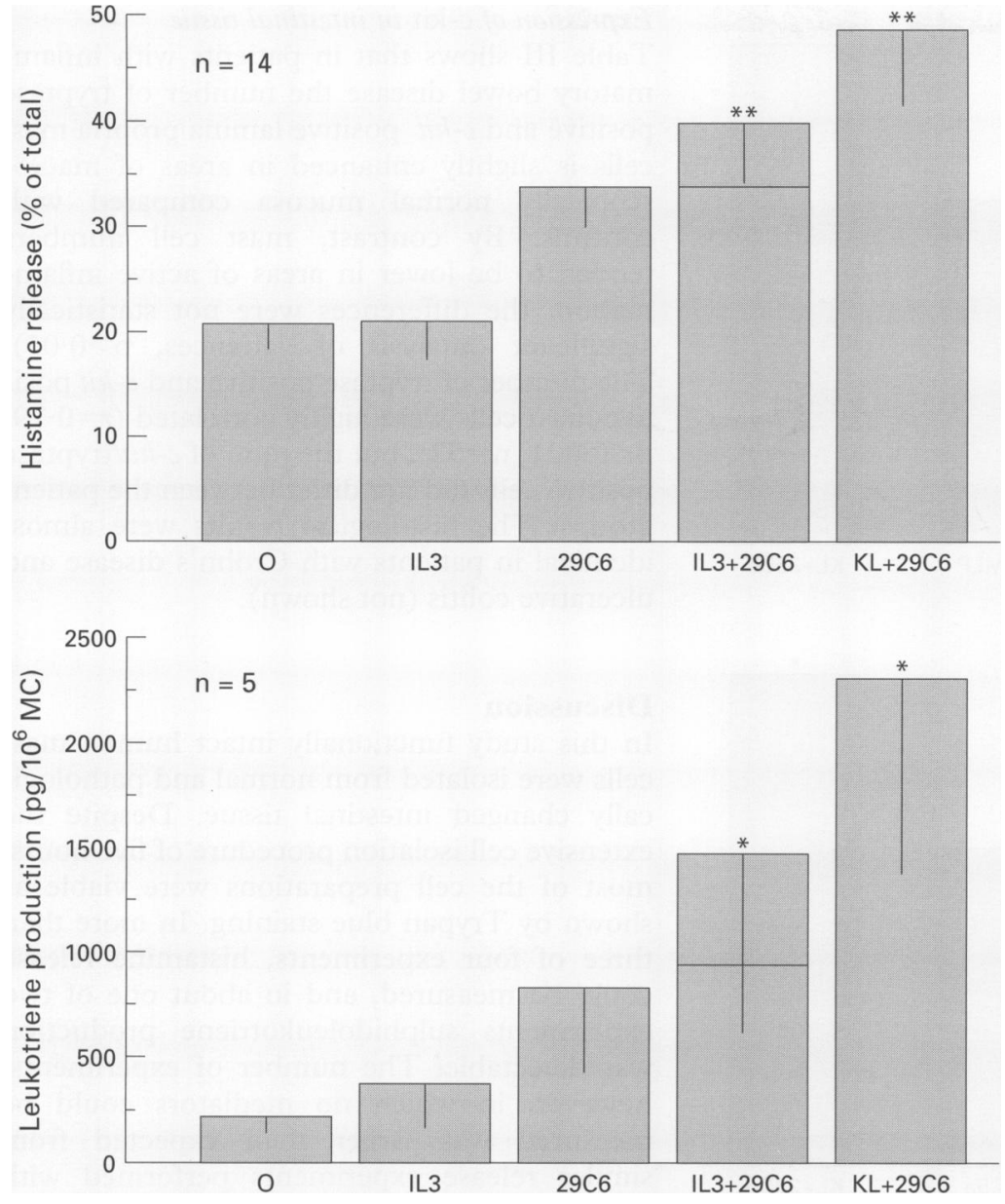

Figure 2: Effect of interleukin 3 (IL 3,10 ng/ml) on mediator release by human intestinal mast cells. The experimental procedure and the concentrations of the other agonists are described in Fig 2. The mean (SEM) of 14 (upper panel, histamine release) and five (lower panel, leukotriene production) experiments performed in duplicate is shown. Statistical analysis (Duncan method, see text): ${ }^{\star} p<0 \cdot 05 ;{ }^{\star \star} p<0.01$ for a significant difference to the spontaneous release $(O)$, other significant differences in histamine release: iono versus IL 3 ( $p<0.01)$, iono versus $29 C 6(p<0.05), K L+29$ C6 versus IL 3 $(p<0.05)$. already lost their granules by prior in vivo stimulation or by cell damage during cell preparation.

\section{Correlation of mediator release in response to} different stimulation protocols

The experiments show a strong correlation between the mediator release in response to $\mathrm{mAb} 29 \mathrm{C} 6$ alone and mAb 29C6 after c-kit ligand preincubation $(r=0.72$ and 0.93 for histamine and leukotriene release, respectively; Fig 4 (C) and (D). The correlation was slightly weaker between the release by $c$-kit ligand $+\mathrm{mAb} 29 \mathrm{C} 6$ and receptor independent ionomycin (Fig 4 (E) and (F)), suggesting that the 'releasability' is not primarily depending on the agonist used for mast cell triggering. A weak positive correlation could be also found between histamine and leukotriene release in response to $c$-kit ligand $+\mathrm{mAb} 29 \mathrm{C} 6(r=0.50$, $\mathrm{p}<0.05, \mathrm{n}=16$, data not shown).

\section{Mast cell counting and mediator release in} patients with inflammatory bowel disease The percentage of mast cells in cell suspensions derived from patients with tumours (normal tissue) and Crohn's disease did not differ significantly (Table II). Also the grade of inflammation and the site of tissue resection did not influence the number of isolated mast cells. Higher mast cell percentages were found, however, if the tissue was processed a day after tissue resection compared with cell preparations isolated within two hours. As it is unlikely that mast cells proliferate under these conditions within 24 hours, a kind of 'reconstitution' of mast cell granules may occur in tissue within 24 hours after resection. This would explain why more mast cells become visible in light microscope examination after one day. The number of eosinophils varied in the cell preparations depending on the kind of disease, the presence of active inflammation, and the site of tissue resection. High eosinophil percentages were found in actively inflamed tissues and in tissue derived from patients with Crohn's disease or ulcerative colitis. Also neutrophils and lymphocytes predominated in preparation derived from actively inflamed tissue or from patients with inflammatory bowel disease. The highest histamine content per mast cell was found in mast cells isolated from patients with Crohn's disease or ulcerative colitis, and in mast cells derived from the small intestine (Table II). Our data suggest that the release reactions are dependent on the diagnosis, the presence of active inflammation, and the site of tissue resection, but not on age, sex or time of tissue processing (analysis of variances, overall $\mathrm{p}<0.05)$. For example, Fig 5 shows that mast cells isolated from actively inflamed tissue (nine Crohn's disease, one ulcerative colitis) release higher amounts of mediators than mast cells from macroscopically normal tissue. Significant differences were seen for histamine release in response to sequential stimulation with $c$-kit ligand and mAb 29C6 the cell suspensions (Fig 4 (B)). This may show that degranulated mast cells may contribute to the leukotriene synthesis. In particular, the cell preparations, in which only small numbers of mast cells were counted, may contain 'invisible mast cells', which have 

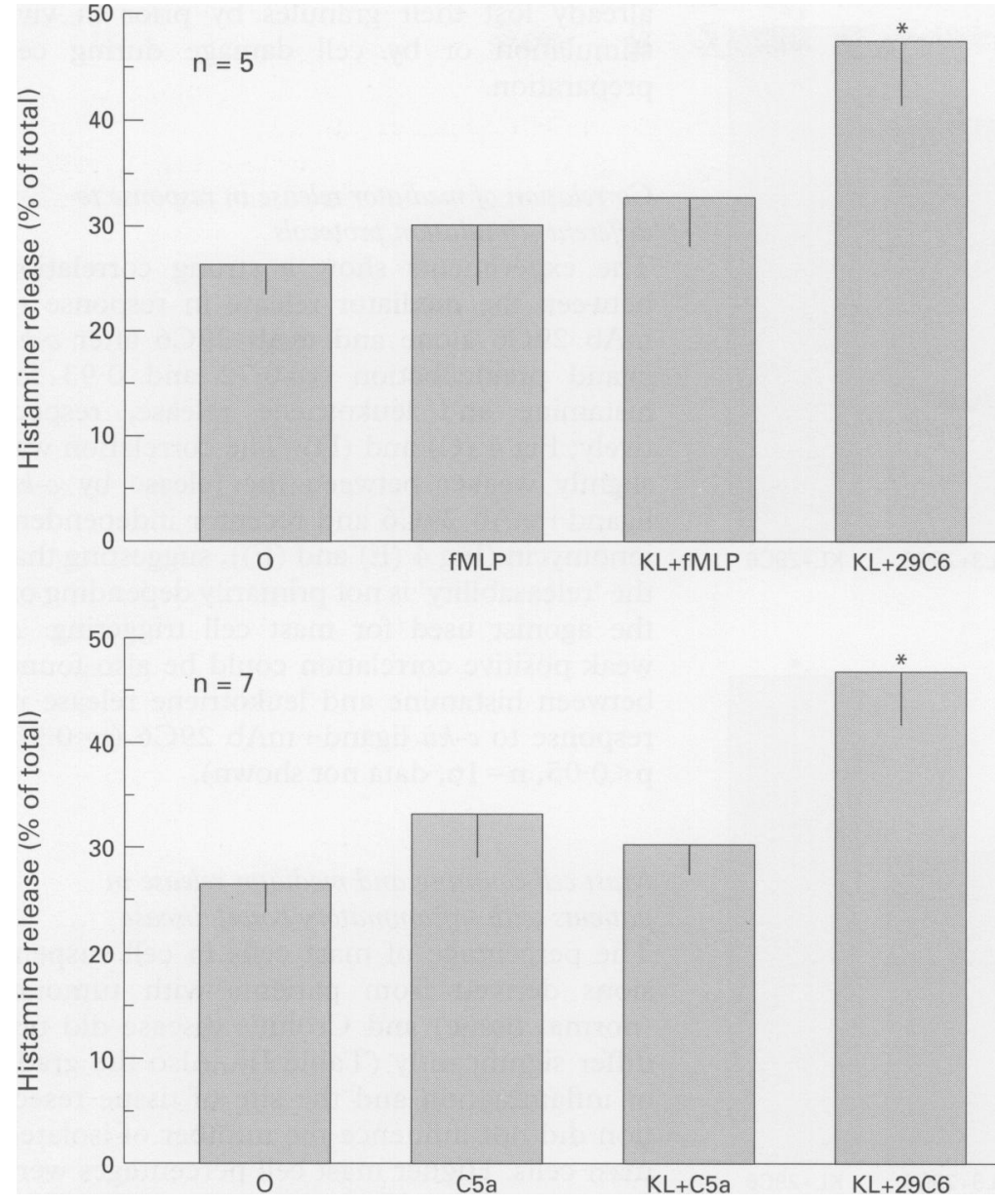

Figure 3: Effect of fMLP and C5a on histamine release by human intestinal mast cells. Cells were preincubated in buffer $(O, f M L P, C 5 a)$ or with c-kit ligand $(K L+f M L P$, $K L+C 5 a, K L+29 C 6)$ and then stimulated with $2 \cdot 5 \mu M$ fMLP (fMLP, KL+fMLP), or $10 \mathrm{nM} C 5 \mathrm{a}(\mathrm{C} 5 \mathrm{a}, \mathrm{KL}+\mathrm{C5a})$, or $100 \mathrm{ng} / \mathrm{ml} \mathrm{mAb} \mathrm{29C6}(\mathrm{KL}+29 \mathrm{C6})$. Other experimental conditions as described for Fig 1. The mean (SEM) histamine release of five (upper panel) and seven (lower panel) experiments performed in duplicate is shown. Statistical analysis (Duncan method, see text): ${ }^{\star} p<0.05$, ${ }^{\star} p<0.01$ for a significant difference to the spontaneous release $(O)$. Analogous results were obtained for sulphidoleukotriene production (data not shown).

$(\mathrm{p}<0.05)$ and for leukotriene production, either spontaneous release $(p<0.05)$ or after stimulation with $c$-kit ligand and mAb 29C6 $(p<0.05)$ or with ionomycin $(p<0.01)$. In three patients with Crohn's disease, both inflamed and macroscopically normal tissue could be obtained. Interestingly, the release reaction was much more pronounced in cells derived from inflamed areas than in cells from uninflamed areas suggesting an association between the release reaction and the activity of the disease (data not shown). In general, there was a tendency to higher release in mast cells from patients with inflammatory bowel disease compared with controls (patients with intestinal tumours or other diseases).

TABLE III Immunohistochemistry

\begin{tabular}{lccc}
\hline & $\begin{array}{l}I B D^{\star} \text { inflamed } \\
(n=21)\end{array}$ & $\begin{array}{l}\text { IBD uninflamed } \\
(n=21)\end{array}$ & $\begin{array}{c}\text { Controls } \\
(n=10)\end{array}$ \\
\hline Age (y) & $39(3)$ & $38(3)$ & $59(3)$ \\
Sex (m:f) & $14: 7$ & $11: 10$ & $5: 5$ \\
Diagnosis (CD:UC) $\dagger$ & $10: 11$ & $10: 11$ & $129(19)$ \\
Tryptase positive MC $\ddagger\left(1 / \mathrm{mm}^{2}\right)$ & $108(18)$ & $166(22)$ & $71(13)$ \\
$c$-kit positive MC (1/mm & $57(15)$ & $97(16)$ & $54(4)$ \\
$c$-kit/tryptase ratio (\%) & $48(6)$ & $55(6)$ & \\
\hline
\end{tabular}

$\star \mathrm{IBD}=$ inflammatory bowel disease $+\mathrm{CD}=$ Crohn's disease, $\mathrm{UC}=$ ulcerative colitis; $\ddagger M C=$ mast cells within the lamina propria of colonic tissue. Data are presented as mean (SEM).

\section{Expression of c-kit in intestinal tissue}

Table III shows that in patients with inflammatory bowel disease the number of tryptase positive and $c$-kit positive lamina propria mast cells is slightly enhanced in areas of macroscopically normal mucosa compared with controls. By contrast, mast cell numbers tended to be lower in areas of active inflammation, the differences were not statistically significant (analysis of variances, $\mathrm{p}>0.05$ ). The number of tryptase positive and $c-k i t$ positive mast cells were highly correlated $(r=0.79$, $\mathrm{p}<0.001, \mathrm{n}=52$ ), but the ratio of $c$-kit/tryptase positive cells did not differ between the patient groups. The histological results were almost identical in patients with Crohn's disease and ulcerative colitis (not shown).

\section{Discussion}

In this study functionally intact human mast cells were isolated from normal and pathologically changed intestinal tissue. Despite the extensive cell isolation procedure of five hours, most of the cell preparations were viable as shown by Trypan blue staining. In more than three of four experiments, histamine release could be measured, and in about one of two experiments sulphidoleukotriene production was detectable. The number of experiments, however, in which no mediators could be measured was larger than expected from similar release experiments performed with peripheral blood leucocytes. ${ }^{18-20}$ Such negative results may be caused by low cell numbers and by the isolation procedure, which is particularly extensive and complicated for the isolation of human intestinal mast cells. Cells may be damaged during the process and the damage is not necessarily visible by classic means such as Trypan blue staining but becomes obvious in functional assays. Possibly, the rather high spontaneous release seen in this study is also a result of the isolation procedure, which may cause some kind of artificial cellular 'leakage'. Alternatively, it could be caused by an in vivo stimulation of the cells. As the spontaneous leukotriene release seems to depend on the presence of inflammation, the site of tissue resection, and the kind of disease of the donors, cell damage may be not the only reason for spontaneous release. Clearly, further studies are needed to elucidate the influence of cell isolation procedures on measurability of mast cell mediators, although the methods used here are suitable to study the regulation of mediator release by human intestinal mast cells.

It is known from previous studies that human intestinal mast cells can be stimulated in vitro for mediator release by calcium-ionophores or ionomycin and by IgE or IgE receptor crosslinking with allergen or mAb. ${ }^{12} 2627$ The amount of mediators released by IgE receptor crosslinking is rather small, however, as confirmed by our findings. We found in 21 of 36 experiments $(=58 \%)$ only marginal histamine release $(<5 \%$ release above spontaneous release) after stimulation with a maximally effective concentration of anti-IgE receptor $\mathrm{mAb}$. Similar results were 

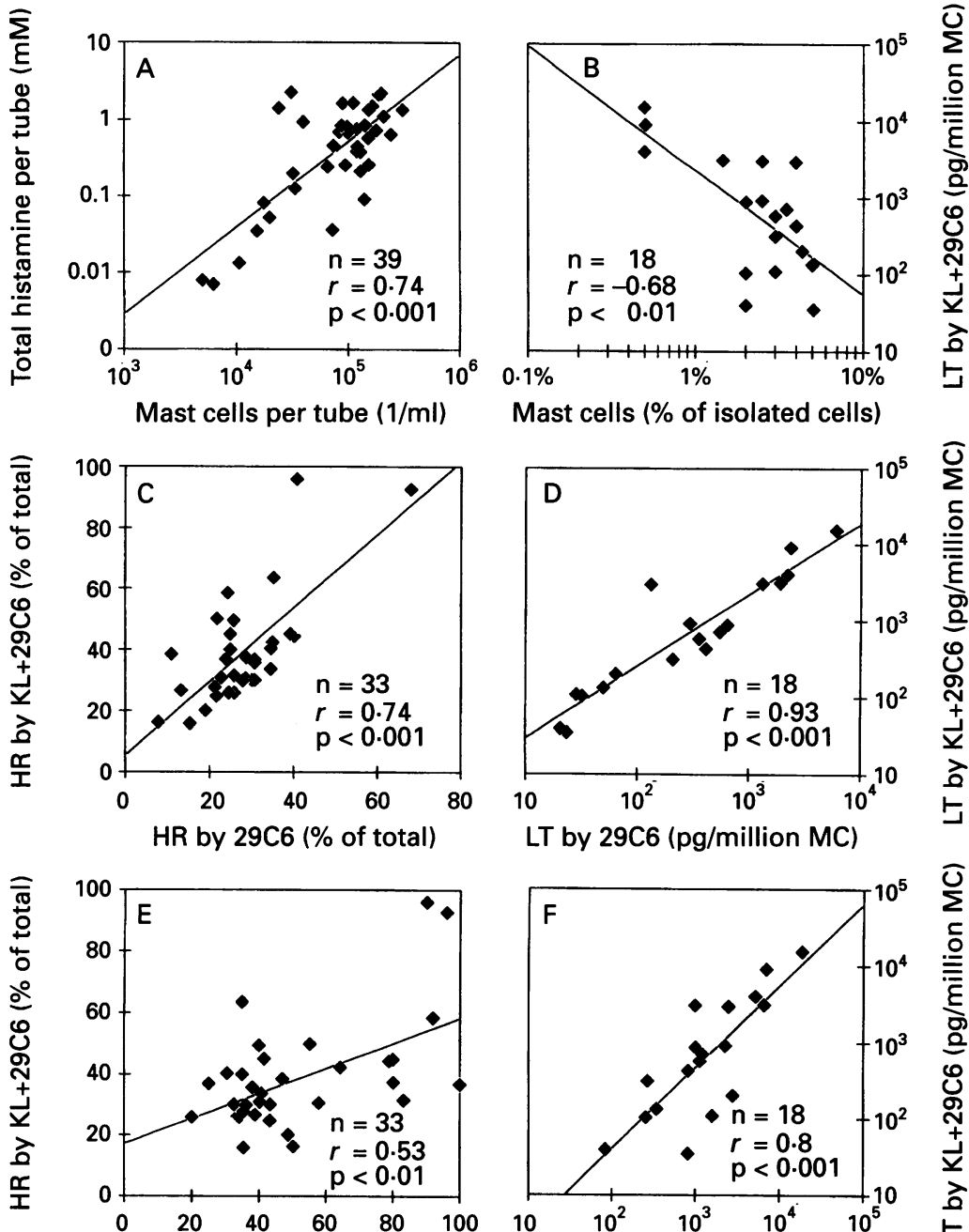

LT by $29 \mathrm{C} 6$ (pg/million MC)

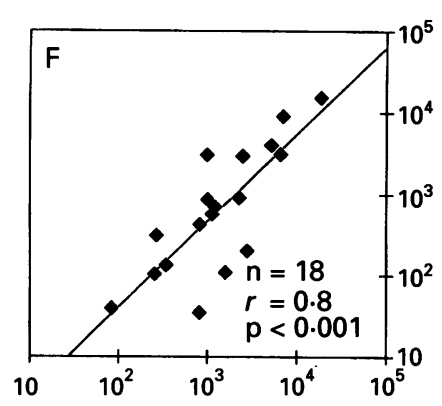

HR by ionomycin (\% of total) LT by ionomycin (pg/million MC)

Figure 4: Correlations. (A) Number of mast cells (MC, $x$ axis, logarithmic) versus tota histamine per tube after cell lysis (y axis, logarithmic). (B) Percentage of mast cells in the cell suspensions used for the experiments ( $x$ axis, logarithmic) versus leukotriene production (LT) induced by KL and $m A b 29 C 6$ ( $y$ axis). (C) Histamine release (HR) and (D) LT induced by the mAb 29C6 without ( $x$ axis) and with ( $y$ axis) c-kit ligand $(K L)$ preincubation. (E) HR and $(F) L T$ induced by ionomycin ( $x$ axis) versus $H R$ induced by the sequential stimulation with $K L$ and $m A b 29 C 6$ ( $y$ axis). Experimental procedures of the release experiments and concentrations of the agonists as described in Fig 1. The number of experiments $(n)$, the correlation coefficient $(\mathrm{r})$, and the probability $(p)$ for the hypothesis that $\mathrm{r}$ is distinct from zero (modified Fisher's test) are shown.

obtained for leukotriene C4 production in response to IgE receptor crosslinking. Thus, IgE receptor crosslinking in itself is a weak agonist for human intestinal mast cells in vitro. The IgE independent agonists C5a and $\mathrm{AMLP}$ failed to induce a significant mediator release. This is in agreement with previous studies on human intestinal and lung mast cells. 1216 26-28 In addition, a number of other agonists known to induce degranulation in human skin mast cells, rat peritoneal mast cells or human basophils, or all three, such as substance $\mathrm{P}, \mathrm{C} 3 \mathrm{a}$, platelet activating factor, and peptides of the chemokine family, have not been tested in human intestinal mast cells but were found to be ineffective in human lung mast cells. ${ }^{162728}$ These data show that IgE receptor crosslinking is the only known receptor dependent signal inducing mediator release in human mucosal mast cells. As it is known that mast cells can degranulate almost completely under certain in vivo conditions (for example, anaphylactic shock reactions), other, as yet unknown, factors such as cytokines should be considered, which are more potent than IgE receptor crosslinking in activating human intestinal mast cells for mediator release, or which enhance the $\mathrm{IgE}$ dependent release reaction.

In this study, we selected two cytokines for examination of their capacity to regulate mediator release in human intestinal mast cells. IL 3 was selected because it is the most established growth factor for rodent mast cells and human basophil progenitors, and it primes mature human basophils for enhanced mediator release. ${ }^{1218-20} C$-kit ligand is a potent growth factor for rodent and human mast cells and a unique cytokine modulating mediator release mechanism in human lung mast cells. ${ }^{1621}$ This study shows that $c$-kit ligand induces the release of small amounts of histamine and sulphidoleukotrienes in human intestinal mast cells being in the same range as the mediator release induced by IgE receptor crosslinking. Most interestingly, the sequential stimulation with $c$-kit ligand and mAb 29C6 induces a mediator release by far exceeding the effects of each agonist. Thus, c-kit ligand potentiates the response of intestinal mast cells towards IgE receptor dependent triggering. In particular, the release of sulphidoleukotrienes in response to mAb $29 \mathrm{C} 6$ is strongly enhanced by $c$-kit ligand. In $c$-kit ligand primed intestinal mast cells, anti-IgE receptor crosslinking induces the release of almost similar amounts of mediators as ionomycin. The enhancing effects of $c$-kit ligand occur within a few minutes of preincubation and seem to be independent of contaminating tissue cells, as partial purification of mast cells did not change the release reaction. Further evidence for a direct effect of $c$-kit ligand on human intestinal mast cells comes from the finding that human mast cells but not mature human basophils bear the $c$-kit ligand receptor. ${ }^{29}$ These data show that $c$-kit ligand may have an important proinflammatory effect on human intestinal mast cells by strongly enhancing the IgE dependent release of preformed and de novo synthesised inflammatory mediators.

The regulation of $c$-kit ligand and its receptor in vivo is largely unknown. Human $c$-kit ligand is expressed in several cell types such as fibroblasts, endothelial cells, bone marrow stromal cells, and tumour cells, either constitutively or upon activation. ${ }^{30-32}$ The human $c$-kit ligand receptor, $c-k i t$, was found in mast cells, basal cells of the skin, epithelial cells of the breast, a subset of natural killer cells, immature bone marrow cells, and in several tumour cells. ${ }^{32-36}$ Interestingly, the expression of $c-k i t$ on mast cells is regulated by IL 4,37 a cytokine produced by $T$ lymphocytes and mast cells, which participates in the induction of allergic immune responses. ${ }^{38}$ Both $c-k i t$ ligand and its receptor exist in a soluble and a membrane bound form. Most probably, c-kit ligand, similar to other cytokines, exerts its regulatory effects in a paracrine manner, although small amounts of $c-k i t$ ligand $(3.3(1 \cdot 1) \mathrm{ng} / \mathrm{ml})$ are also detectable in the circulation. ${ }^{39}$ At present, almost no information is available on the level and the form of expression of $c$-kit ligand in disease. It has been reported that normal 

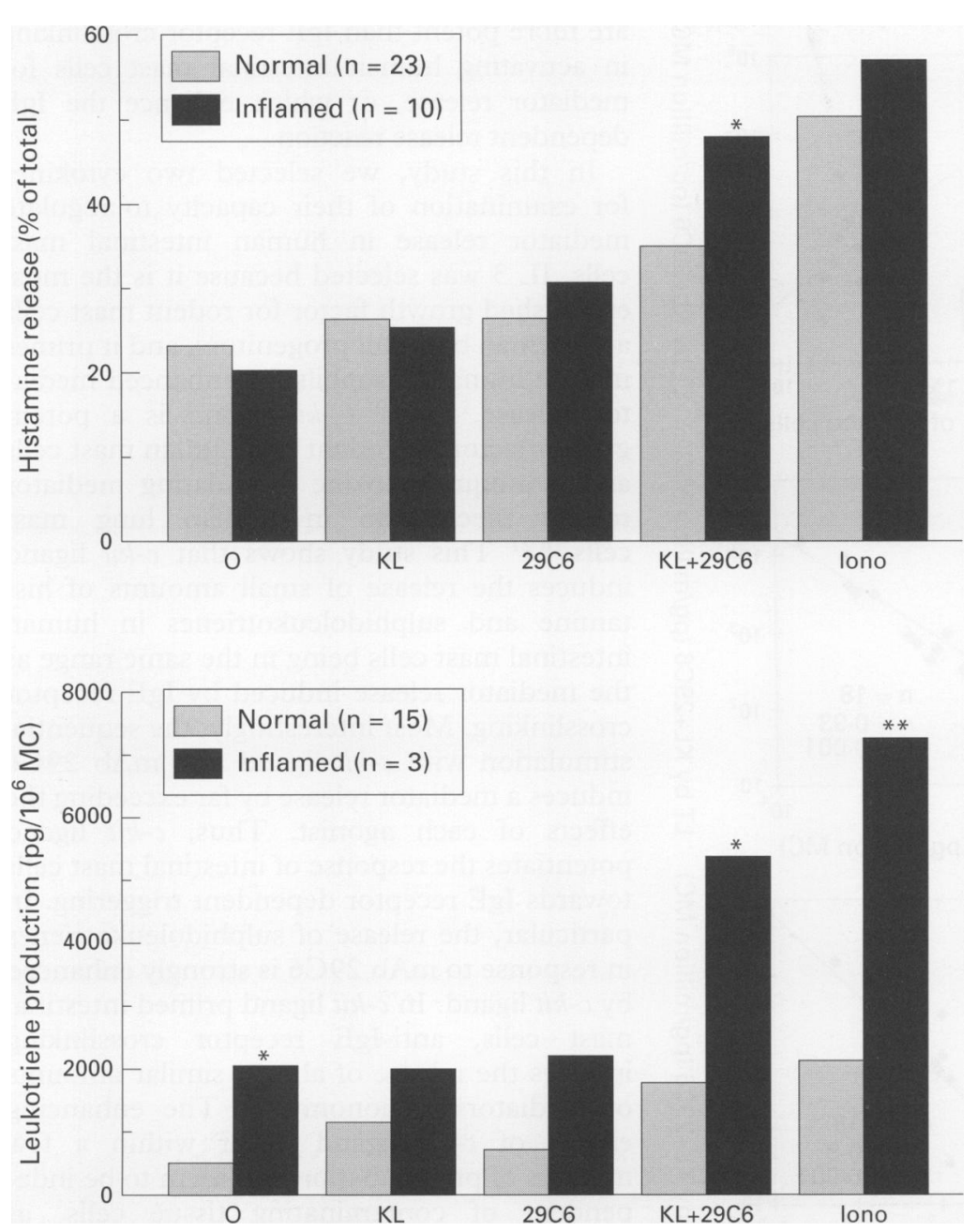

Figure 5: Mediator release in mast cells isolated from macroscopically normal (16 tumour patients, three Crohn's disease, four others) and actively inflamed (nine Crohn's disease, one ulcerative colitis) tissue. The same experiments as in Fig 1 are shown. Analogous differences in mediator release between mast cells isolated from normal and inflamed tissue were seen in experiments shown in Figs 2 and 3. Upper panel: mean of histamine release (all SEM $<10 \%$ ), lower panel: mean of leukotriene production (all $S E M<40 \%$ ). Statistical analysis (two tailed $\mathrm{t}$ test for independent samples): ${ }^{\star} p<0.05,{ }^{\star \star} p<0.01$ for a significant difference between mediator release in mast cells isolated from normal and inflamed tissue. mediated by contaminating cells such as basophils, eosinophils or monocytes bearing the high affinity IL 3 receptor. Purified mast cell preparations are needed to study the mechanism of IL 3 effect on intestinal mast cell mediator release.

The mediator release in intestinal mast cells is subjected to a large variability, which is independent of the stimulus used for cell activation. This variability may be dependent on the presence of tissue inflammation, the kind of disease the donor suffers from, and yet unknown genetic factors. In this study, data from different patients were pooled together, which surely augment the variability. For example, Fig 5 shows that the presence of tissue inflammation in patients with inflammatory bowel disease is a relevant factor for the outcome of the release reaction. Previous studies showed, however, that a considerable variability of mediator release can be seen even in healthy persons. The phenomenon, which has been termed 'releasability', has been extensively studied in human basophils (reviewed in ref 3 ). The mechanism of releasability and the factors influencing it (in vivo priming by cytokines, genetic factors?) have not yet been clearly defined. Statistical analysis of data becomes difficult for such reasons, particularly, if tests for comparison of multiple means (analysis of variances) not reflecting paired data are used. The fact that nevertheless statistically significant differences were found between patients with inflammatory bowel disease and controls emphasises the potential role of mast cells in the pathogenesis of chronic intestinal inflammation.

Our data suggest that the spontaneous and the induced release of histamine and in particular of leukotrienes is enhanced in mast cells isolated from actively inflamed tissues from patients with inflammatory bowel disease (most of them with Crohn's disease) compared with the release in mast cells isolated from macroscopically normal tissue derived from tumour patients. Particularly, the inducible release of leukotrienes was considerably lower in mast cells derived from uninflamed Crohn's tissue than in mast cells from inflamed Crohn's tissue. These findings extend the findings by Knutson et al ${ }^{10}$ who showed an increased spontaneous histamine secretion rate in vivo in patients with active Crohn's disease, and suggested that mast cell activation participates in Crohn's disease. More recently, Casellas et $a^{11}$ found an increased intraluminal secretion of LTC4 in Crohn's disease patients showing that our in vitro findings are indeed of relevance in vivo. The in vitro release of mast cell mediators in patients with inflammatory bowel disease has been examined in two studies. Sanderson et al ${ }^{40}$ reported no difference in histamine release from biopsy specimens of inflamed tissue derived from children with Crohn's disease. By contrast Fox et al 12 found that release of preformed histamine and newly synthesised lipid mediators induced by IgE crosslinking was enhanced in mast cells isolated from actively inflamed tissue derived from patients with ulcerative colitis compared may be surprising as human lung mast cells do not respond to IL 3. ${ }^{16}$ It has been shown that human lung mast cells lack the IL 3 receptor, ${ }^{17}$ analogous studies with human intestinal mast cells have not yet been performed. It is probable that the enhancing effect of IL 3 is 
with control tissue. The mechanism of enhanced mediator release in patients with inflammatory bowel disease is unclear. It may be speculated that increased expression of $c$-kit or $c$-kit ligand may be involved. Our data show that the portion of $c$-kit positive mast cells in the lamina propria is similar in patients with and without active inflammation and in controls. It has not yet been examined whether $c$-kit ligand synthesis is increased in areas of active inflammation in the course of inflammatory bowel disease.

Mast cells and their mediators have been associated with a number of gastrointestinal diseases such as food hypersensitivity, inflammatory bowel disease, coeliac disease, chronic idiopathic diarrhoea, motility disorders, and helminth infections. ${ }^{7-14}$ These disorders have in common that their aetiology or pathophysiology, or both, is largely unclear. Because of the well defined role of mast cell in allergic reactions, it is obvious that mast cells participate in the pathogenesis of intestinal hypersensitivity reactions. ${ }^{71-43}$ It is tempting to speculate that mast cells are also of importance in other inflammatory diseases of the intestine. It is questionable, however, whether such diseases are always IgE dependent. The definition of IgE independent mast cell agonists such as $c$-kit ligand or the recently described epithelial cell derived proteins ${ }^{44}$ capable of triggering mast cells for mediator release or enhancing the release reaction induced by other secretagogues may be of particular relevance for these disorders. Therefore, further studies are necessary to examine the expression of $c$-kit ligand and its receptor in disease, and to correlate these data with the in vivo release of mast cell mediators.

This work was supported by the Deutsche Forschungsgemeinschaft (SFB 280-C8). The authors thank Drs R Chizzonite and J P Kochan (Hoffmann-La Roche, Nutley, NJ) for providing the mAb 29C6; Drs H W Lahm and $H$ Langen (Hoffmann-La Roche, Basle, Switzerland), Drs $M$ Schreier and E Liehl (Sandoz Ltd, Basle, Switzerland and gifts of cytokines.

1 Stevens RL, Austen KF. Recent advances in the cellular and molecular biology of mast cells. Immunol Today 1989; 10: 381-6.

2 Galli SJ. New concepts about the mast cell. $N$ Engl f Med 1993; 328: 257-65.

3 Bischoff SC. Human basophils and mast cells: mediato cells between allergic inflammation and the specific mmune system. Immun Infect 1994; 22: 93-103.

4 Metcalfe DD. Mast cell mediators with emphasis on intestinal mast cells. Ann Allergy 1984; 53: 563-75.

5 De Weck AL, Dahinden CA, Bischoff SC. The multiple role of cytokines in IgE-mediated allergic reactions. Behrin Inst Mitt 1992; 91: 100-6.

6 Fujimoto K, Imamura I, Granger DN, Wada H, Sakata T, Tso $P$. Histamine and histidine decarboxylase are correlated with mucosal repair in rat small intestine after ischemia-reperfusion. $\mathcal{F}$ Clin Invest 1992; 89: 126-33.

7 Crowe SE, Perdue MH. Gastrointestinal food hypersensitivity: basic mechanisms of pathophysiology. Gastroenterology 1992; 103: 1075-95.

8 Marsh MN, Hinde J. Inflammatory component of celiac sprue mucosa. I. Mast cells, basophils, and eosinophils. Gastroenterology 1985; 89: 92-101.

9 Else KJ, Finkelman FD, Maliszewski CR, Grencis RK Cytokine-mediated regulation of chronic intestinal helminth infection. $\mathcal{F}$ Exp Med 1994; 179: 347-51

10 Knutson L, Ahrenstedt Ö, Odling B, Hällgren R. The ejunal secretion of histamine is increased in active Crohn's disease. Gastroenterology 1990; 98: 849-54.

11 Casellas F, Guarner F, Antolin M, Rodriguez R, Slas A Malagelada JR. Abnormal leukotriene C4 release by unaffected jejunal mucosa in patients with inactive Crohn's disease. Gut 1994; 35: 517-22.

12 Fox CC, Lazenby AJ, Moore WC, Yardley JH, Bayless TM Lichtenstein LM. Enhancement of human intestinal mast cell mediator release in active ulcerative colitis. Gastroenterology 1990; 99: 119-24.

13 Crowe SE, Perdue MH. Anti-immunoglobuline E-stimulated ion transport in human large and small intestine. Gastroenterology 1993; 105: 746-72.

14 Baum CA, Bhatia P, Miner PB. Increased colonic mucosal mast cells associated with severe watery diarrhea and microscopic colitis. Dig Dis Sci 1989; 34: 1462-5.

15 Lawrence ID, Warner JA, Cohan VL, Hubbard WC Kagey-Sobotka A, Lichtenstein LM. Purification and characterization of human skin mast cells. Evidence for human mast cell heterogeneity. F Immunol 1987; 139: 3062-9.

16 Bischoff SC, Dahinden CA. C-kit ligand: a unique potentiator of mediator release by human lung mast cells. $\mathcal{F}$ Exp Med 1992; 175: 237-44.

17 Valent P, Besemer J, Sillaber C, Butterfield JH, Eher R, Majdic $\mathrm{O}$, et al. Failure to detect IL-3 binding sites on human mast cells. F Immunol 1990; 145: 3432-7.

18 Kurimoto $\mathrm{Y}$, de Weck AL, Dahinden CA. The effect of interleukin 3 upon IgE-dependent and IgE-independent basophil degranulation and leukotriene generation. Eur f Immunol 1991; 21: 361-8.

19 Bischoff SC, Brunner T, De Weck AL, Dahinden CA Interleukin 5 modifies histamine release and leukotriene generation by human basophils in response to diverse agonists. F Exp Med 1990; 172: 1577-82.

20 Bischoff SC, Dahinden CA. Effect of nerve growth factor on the release of inflammatory mediators by mature humane basophils. Blood 1992; 79: 2662-9.

21 Galli SJ, Zsebo KM, Geissler EN. The kit ligand, stem cell actor. Adv Immunol 1994; 55: 1-96.

22 Bischoff SC, Dahinden CA. Effect of $c$-kit ligand on mediator release by human lung mast cells. Int Arch Allergy Immunol 1992; 99: 319-22.

23 Columbo M, Horowitz EM, Botana LM, MacGlashan DW Jr, Bochner BS, Gillis S, et al. The human recombinant $c$-kit receptor ligand, rhSCF, induces mediator release from human cutaneous mast cells and enhances IgEdependent mediator release from both skin mast cells and peripheral blood basophils. $f$ Immunol 1992; 149: 599-608.

24 Longley J, Morganroth GS, Tyrrell L, Ding TG, Anderson $\mathrm{DM}$, Williams DE, et al. Altered metabolism of mast cell growth factor (c-kit ligand) in cutaneous mastocytosis. growth factor (c-kit ligand) in cut

25 Godfrey $\mathrm{K}$. Comparing the means of several groups. In Bailer JC, Mosteller F, eds. Medical uses of statistics. 2nd edition. Boston: N Engl J Med Books, 1992

26 Lowman MA, Rees PH, Benyon RC, Church MK. Human mast cell heterogeneity: histamine release from mast cells dispersed from skin, lung, adenoids, tonsils, and colon in response to IgE-dependent and non-immunologic stimuli. f Allergy Clin Immunol 1988; 81: 590-7.

27 Liu WL, Bosman L, Boulos PB, Lau HYA, Pearce FL Mast cells from human colonic mucosa and submucosa/muscle: a comparison with human lung mast cells. Agents Actions 1990; 30: 70-3.

28 Schulman ES, Post TJ, Henson PM, Giclas PC. Differential effects of the complement peptides, C5a and C5a des Arg on human basophil and lung mast cell histamine release. f Clin Invest 1988; 81: 918-23.

29 Valent P, Majdic O, Maurer D, Bodger M, Muhm M, Bettelheim P. Further characterization of surface membrane structures expressed on human basophils and mast cells. Int Arch Allergy Appl Immunol 1991; 91: 198-202.

30 Heinrich MC, Dolley DC, Freed AC, Band L, Hoatlin ME, Keeble WW, et al. Constitutive expression of steel factor gene by human stromal cells. Blood 1993; 82: 771-83.

31 Broudy VC, Kovach NL, Bennett LG, Lin N, Jacobson FW, Kidd PG. Human umbilical vein endothelial cells display high-affinity $c$-kit receptors and produce a soluble display high-affinity $c-k i t$ receptors and produce a sol
form of the $c$-kit receptor. Blood $1994 ; 83: 2145-52$.

32 Inoue $M$, Kyo S, Fujita $M$, Enomoto T, Kondoh G. Coexpression of the c-kit receptor and the stem cell factor in gynecological tumors. Cancer Res 1994; 54 3049-53.

33 Matos ME, Schnier GS, Beecher MS, Ashman LK, Williams DE, Caligiuri MA. Expression of a functiona $c$-kit receptor on a subset of natural killer cells. $\mathcal{f} \operatorname{Exp} M e d$ 1993; 178: 1079-84.

34 Matsuda R, Takahashi T, Nakamura S, Sekido Y, Nishida $\mathrm{K}$, Seto $\mathrm{M}$, et al. Expression of the $c$-kit protein in human solid tumors and in corresponding fetal and adult normal tissues. Am F Pathol 1993; 142: 339-46.

35 Tsuura Y, Hiraki H, Watanabe K, Igarashi S, Shimamura $\mathrm{K}$, Fukuda T, et al. Preferential localization of $c-k i t$ product in tissue mast cells, basal cells of the skin, epitheial cells of breast, small cell lung carcinoma and seminoma/dysgerminoma in human: immunohistochemical study on formalin-fixed, paraffin-embedded tissues. Virchows Arch 1994; 424: 135-41.

36 Toyota M, Hinoda Y, Itoh F, Takaoka A, Imai K, Yachi A Complementary DNA cloning and characterization of truncated form of $c-k i t$ in human colon carcinoma cells. Cancer Res 1994; 54: 272-5.

37 Sillaber C, Strobl H, Bevec D, Ashman LK, Butterfield JH, Lechner $\mathrm{K}$, et al. IL-4 regulates c-kit proto-oncogene product expression in human mast and myeloid progenitor cells. F Immunol 1991; 147: 4224-8.

38 Bradding P, Feather IH, Howarth PH, Mueller R, Roberts JA, Britten $\mathrm{K}$, et al. Interleukin 4 is localized to and released by human mast cells. $\mathcal{F}$ Exp Med 1992; 176: 1381-6. 
39 Langley KE, Bennett LG, Wypych J, Yancik SA, Liu XD, Westcott KR, et al. Soluble stem cell factor in human serum. Blood 1993; 81: 656-60.

40 Sanderson IR, Leung KPB, Pearce FL, Walker-Smith JA Lamina propria mast cells in biopsies from children with Crohn's disease. 7 Clin Pathol 1986; 39: 279-83.

41 Cherner JA, Jensen RT, Dubois A, O'Doriso TM, Gardner JD, Metcalfe DD. Gastrointestinal dysfunction in systemic mastocytosis. A prospective study. Gastroenterology

42 Selbekk BH. A comparison between in vitro jejunal mast cell degranulation and intragastric challenge in patients with suspected food intolerance. Scand $\mathcal{F}$ Gastroenterol 1985; 20: 299-303.

43 Sampson HA, Mendelson L, Rosen IP. Fatal and near-fatal anaphylactic reactions to food in children and adolescents. N Engl f Med 1992; 327: 380-4.

44 Fox CC, Lichtenstein LM, Roche JK. Intestinal mast cell responses in idiopathic inflammatory bowel disease. Histamine release from human intestinal mast cells in response to gut epithelial proteins. Dig Dis Sci 1993; 38: $1105-12$ 